\title{
Field performance and genetic analysis of selected tomato (Lycopersicon esculentum Mill.) genotypes
}

\author{
R. Y. Mitul, M. A. Haque*, S. A. Rima and S. N. Begum ${ }^{1}$ \\ Department of Genetics and Plant Breeding, Bangladesh Agricultural University, Mymensingh-2202, Bangladesh and \\ ${ }^{1}$ Plant Breeding Division, Bangladesh Institute of Nuclear Agriculture, Mymensingh-2202, Bangladesh. \\ *E-mail: ashraf_gpb2000@yahoo.com
}

\begin{abstract}
The study was carried out in the field laboratory of the Department of Genetics and Plant Breeding of Bangladesh Agricultural University in order to evaluate varietal performance and genetic variability of fourteen tomato genotypes based on morphological and biochemical characteristics. Tomato genotypes were collected from Genetics and Plant Breeding farm, Bangladesh Agricultural University, Mymensingh. The field experiment was conducted from October 2014 to March 2015 with Randomized Complete Block Design (RCBD) including three replications. Data for genetic analyses were collected on seven traits viz. days to first flowering, pollen grain fertility, days to first fruit maturity, individual fruit weight, plant height, ascorbic acid content and yield per plant. ANOVA showed significant variation among the tomato genotypes for all the traits. Wide range existed between minimum and maximum mean values for all the genotypes whereas genotype World champion had the maximum individual fruit weight with the highest yield. On the other hand, genotype $\mathrm{Cl}-170-0-20-2-0$ gave poor performance. Yield exhibited a positive significant correlation with individual fruit weight; and in path coefficient analysis, maximum positive direct effects were found through individual fruit weight followed by plant height, ascorbic acid content and days to first fruit maturity. In principal component analysis, the main three components contributed approximately $79.14 \%$ of total variability. Genotypes were classified into five clusters by Ward's method including late maturing and low yielder genotypes in cluster I, early flowering genotypes in cluster II, high yielder with large fruited genotypes in cluster III, genotypes containing low ascorbic acid in cluster IV and genotypes having early maturity with small fruit but minimum pollen grains fertility rate in cluster V. Based on the present findings, World champion and Big cherry were considered as superior varieties among the fourteen genotypes and individual fruit weight might be considered as an important criteria for yield improvement.
\end{abstract}

Keywords: Genetic variability, Morphological characteristics, Biochemical characteristics, Tomato, Lycopersicon esculentum

\section{Introduction}

Tomato (Lycopersicon esculentum Mill.) is one of the most popular vegetables around the world. It belongs to the genus Lycopersicon and is a member of the family Solanaceae. Tomato is a diploid crop (with 24 somatic chromosomes, relatively small genome size, $950 \mathrm{Mb}$ per haploid nucleus) plant and can be reproduced by both seed and vegetative propagations. Cultivated tomato is the second most commonly consumed vegetable, just next to potato (FAO, 2008). It is believed that tomato was first grown in South America (Ali et al., 2012), in the region of modern day Peru and Ecuador; and due to its crop value it has become a demandable crop throughout the world (Taylor, 1986). Tomato is a very nutritious vegetable and contains a powerful antioxidant called lycopene which acts as an anti-carcinogen (Bhutani and Kallo, 1983). Tomato is a model crop for genetic analysis as it is a source of useful genes which can be used for crop quality improvement, breeding programs to transfer useful gene to the cultivated varieties, and against disease resistance (Bai and Lindhout, 2007; Gur and Zamir, 2004). Tomato is cultivated almost all around the world and the top five tomato producing countries are China, India, United States, Turkey and Egypt, respectively. In Bangladesh, its production is around $9.96 \mathrm{t} \mathrm{ha}^{-1}$ (FAOSTAT, 2012), which is very low as compared to other countries. Now-a-days, tomato is very popular not only to the consumers for its health value but also to the farmers for its high market value and as well as to the researchers for its genetic and genomic characters. To meet the increasing demand of tomato, it is important to study the genetic variability of tomato as variability assessment among tomato genotypes helps to maintain and utilize germplasm resources for the improvement of the cultivars (Reddy et al., 2013). Morphological traits play a vital role in determining the important characters, variability and genetic relationship among the genotypes (Osei et al., 2014). Tomato fruit yield is the final result which is associated with other yield contributing traits and theses traits again interrelated among them (Islam and Khan, 1991). So, looking at this complex relationship is useful to obtain better yield. 
The objectives of the present study were to compare and study the field performance and genetic variability of tomato genotypes for yield and yield contributing characters and assess Principal Component Analysis of yield and other agronomic traits.

\section{Materials and Methods}

The investigation material comprised of fourteen tomato genotypes (i.e. Marglobe-II, Burpi big, Hekari, World Champion, Florida I, Homeastid, Big cherry, Cl-170-0-20-2-0, Derinia, Cl-3d-0-99, Cl-3d-143-0-13, Hot sent, Okiton no.9, Manik) collected from the Genetics and Plant Breeding farm of Bangladesh Agricultural University; and the field trial was carried out in the experimental farm of the department of Genetics and Plant Breeding of the same university, in a Randomized Complete Block Design (RCBD) with three replications. Thus the total number of plots came to forty two $(14 \times 3)$. Plot size was $6.25 \mathrm{~m}^{2}$ $(2.5 \mathrm{~m} \times 2.5 \mathrm{~m})$ with fourteen rows and five plants in each row. Row to row distance was $60 \mathrm{~cm}$ and plant to plant distance was $40 \mathrm{~cm}$. During the growing period, the average maximum and minimum temperature was $28.77^{\circ} \mathrm{C}$ and $18.97^{\circ} \mathrm{C}$, respectively; average relative humidity was $77.90 \%$, and texturally, the soil was sandy loam with $\mathrm{pH}$ value of 6.5 . The average monthly rainfall of the locality was $2.6 \mathrm{~mm}$. The sowing was conducted on 20 October, 2014 and 30 days old seedlings were transplanted in the main field on 20 November, 2014. When the seedlings were well established, $1^{\text {st }}$ mulching and weeding were done uniformly in all plots. Second weeding was done after 20 days of the first one. Mechanical support was provided to the growing plants by bamboo sticks to keep them erect.

Data were collected on seven parameters namely; days to first flowering (days), pollen grain fertility (\%), days to first fruit maturity (days), individual fruit weight $(\mathrm{gm})$, plant height $(\mathrm{cm})$, ascorbic acid content $(\mathrm{mg}$ $\%$ ) and yield per plant $(\mathrm{Kg})$ by individual plant basis. For counting the number of fertile and sterile pollen grains under microscope, four flowers per plant of each variety were taken in the laboratory where IKI (lodine Potassium lodide) was used to stain the pollen grains and mean of the fertile pollen grains expressed in percentage was estimated. Ascorbic acid was extracted with $6 \%$ metaphosphoric acid from well ripen tomato fruits and estimated by the method of Plummer (1971).

Analysis of variance of the data was performed by PLABSTAT software and then correlation coefficient was estimated by the formula suggested by Weber and Moorthy (1952) and path coefficient was made by Dewey and Lu's (1959) formula. Principal Component Analysis was conducted by Holland (2008) method, and Dendrogram was constructed by Ward's method based on squared Euclidean distance.

\section{Results and Discussion}

Significant differences were observed among the genotypes for all the characters (Table 1). The days to first flowering required maximum 74.64 days and minimum 82.50 days and the percentage of pollen grain fertility ranged from $46.00 \%$ to $99.09 \%$. In case of days to first fruit maturity, mean value ranged between 128.60 days and 135.10 days. Individual fruit weight varied from $23.75 \mathrm{gm}$ to $47.07 \mathrm{gm}$, plant height ranged from $41.34 \mathrm{~cm}$ to $138.30 \mathrm{~cm}$, ascorbic acid content varied from $15.52 \mathrm{mg} \%$ to $31.35 \mathrm{mg} \%$ and yield per plant ranged between $0.250 \mathrm{Kg}$ and $0.861 \mathrm{Kg}$. Among all the genotypes, World Champion had the maximum fruit weight $(47.07 \mathrm{gm})$ as well as maximum yield $(0.861 \mathrm{Kg})$, and Big cherry was early flowering (74.64 days) and high yielder $(0.779 \mathrm{Kg})$ genotype (Table 1). On the other hand, Cl-170-0-20-20 and Hot sent gave the worst performances. Coefficient of variation ranged between $1.83 \%$ for days to first fruit maturity and $8.71 \%$ for yield per plant (Table 1). In the correlation coefficient analysis, individual fruit weight showed positive significant correlation with yield per plant (Table 2). Similar result was also reported by Dudi and Kalloo (1982). The path analysis exhibited that individual fruit weight, plant height, ascorbic acid content and days to first fruit maturity had direct positive effect on yield which indicated them as the main contributors for yield (Table 2). Singh et al. (2004) and Reddy et al. (2013) observed similar results in their investigations. Considering the result of correlation coefficient and path analysis, it can be said that individual fruit weight is the most important factor for improving plant yield. 
Table 1. Mean performance of various growth parameters and yield components of $\mathbf{1 4}$ tomato genotypes

\begin{tabular}{|c|c|c|c|c|c|c|c|}
\hline Genotypes & $\begin{array}{c}\text { DFF } \\
\text { (days) }\end{array}$ & $\begin{array}{c}\text { PGF } \\
(\%)\end{array}$ & $\begin{array}{l}\text { DFFM } \\
\text { (days) }\end{array}$ & $\begin{array}{l}\text { IFW } \\
\text { (gm) }\end{array}$ & $\begin{array}{c}\mathbf{P H} \\
(\mathrm{cm})\end{array}$ & $\begin{array}{c}\text { AAc } \\
(\mathrm{mg} \%)\end{array}$ & $\begin{array}{l}\text { Y/P } \\
(\mathrm{Kg})\end{array}$ \\
\hline Marglobe-II & 79.64abc & $99.09 a$ & 132.50abc & $24.09 \mathrm{~h}$ & $107.20 \mathrm{~b}$ & $31.35 a$ & $0.520 d$ \\
\hline Burpi big & 77.78abcd & $98.19 a$ & 132.90abc & 24.59gh & $79.50 d$ & 22.41ef & $0.369 f g$ \\
\hline Hekari & $75.00 \mathrm{~cd}$ & $46.00 \mathrm{~h}$ & $129.70 b c$ & $29.09 \mathrm{ef}$ & $41.34 \mathrm{~h}$ & 18.96gh & $0.471 \mathrm{de}$ \\
\hline World Champion & 80.08ab & 86.00de & $133.60 \mathrm{ab}$ & $47.07 a$ & $92.57 c$ & $25.86 \mathrm{~cd}$ & $0.861 a$ \\
\hline Florida I & $80.33 a b$ & $91.95 b c$ & 133.90ab & $34.71 \mathrm{~cd}$ & $67.95 \mathrm{e}$ & 24.13de & $0.691 \mathrm{c}$ \\
\hline Homeastid & 78.27abcd & 83.33ef & $128.60 \mathrm{c}$ & $29.32 e$ & $66.40 \mathrm{e}$ & $17.24 \mathrm{hi}$ & 0.479 de \\
\hline Big cherry & $74.64 d$ & $72.46 \mathrm{~g}$ & $132.40 a b c$ & $35.91 \mathrm{c}$ & $96.37 c$ & $20.69 f g$ & $0.779 \mathrm{~b}$ \\
\hline Cl-170-0-20-2-0 & $80.33 a b$ & $80.00 f$ & $135.10 \mathrm{a}$ & $25.10 \mathrm{gh}$ & $62.97 \mathrm{ef}$ & $27.58 b c$ & $0.250 \mathrm{~h}$ \\
\hline Derinia & 78.69abcd & $96.00 \mathrm{ab}$ & $135.10 a$ & $26.93 \mathrm{fg}$ & $56.60 \mathrm{~g}$ & $20.68 f g$ & 0.401 ef \\
\hline Cl-3d-0-99 & 78.07abcd & 47.06h & $129.50 \mathrm{bc}$ & $23.75 \mathrm{~h}$ & $138.30 a$ & $18.96 \mathrm{gh}$ & $0.511 d$ \\
\hline Cl-3d-143-0-13 & 78.15abcd & $93.87 a b c$ & 132.70abc & $33.27 d$ & $55.96 \mathrm{~g}$ & $15.52 i$ & $0.368 \mathrm{fg}$ \\
\hline Hot sent & 80.00ab & $90.34 \mathrm{~cd}$ & $134.90 \mathrm{a}$ & $25.39 \mathrm{gh}$ & $53.57 \mathrm{~g}$ & $25.86 \mathrm{~cd}$ & $0.300 \mathrm{gh}$ \\
\hline Okiton no.9 & $82.50 a$ & $99.01 a$ & $132.90 a b c$ & $40.71 b$ & $59.58 \mathrm{fg}$ & $29.31 \mathrm{ab}$ & $0.368 \mathrm{fg}$ \\
\hline Manik & $76.06 \mathrm{bcd}$ & $85.71 \mathrm{de}$ & 133.30ab & $30.51 \mathrm{e}$ & $92.70 \mathrm{c}$ & 24.13de & $0.429 \mathrm{ef}$ \\
\hline SD & 2.20 & 17.46 & 2.05 & 6.94 & 26.17 & 4.66 & 0.178 \\
\hline Minimum & 74.64 & 46.00 & 128.60 & 23.75 & 41.34 & 15.52 & 0.250 \\
\hline Maximum & 82.50 & 99.09 & 135.10 & 47.07 & 138.29 & 31.35 & 0.861 \\
\hline Mean & 78.54 & 83.50 & 132.65 & 30.74 & 76.50 & 23.05 & 0.486 \\
\hline $\mathrm{CV}(\%)$ & 3.17 & 3.47 & 1.83 & 4.20 & 4.50 & 5.30 & 8.71 \\
\hline Level of significance & * & $* *$ & * & $* *$ & $* *$ & $* *$ & $* *$ \\
\hline
\end{tabular}

DFF - Days to first flowering; PGF - Pollen grain fertility, DFFM - Days to first fruit maturity; IFW - Individual fruit weight; PH - Plant height; AAc - Ascorbic Acid content; Y/P - Yield per plant

Table 2. Path co-efficient analysis showing the direct and indirect effect of different yield contributing traits on fruit yield

\begin{tabular}{lccccccc}
\hline \multicolumn{1}{c}{ Characters } & $\begin{array}{c}\text { DFF } \\
(\text { days })\end{array}$ & $\begin{array}{c}\text { PGF } \\
(\%)\end{array}$ & $\begin{array}{c}\text { DFFM } \\
(\text { days })\end{array}$ & $\begin{array}{c}\text { IFW } \\
(\mathrm{gm})\end{array}$ & $\begin{array}{c}\mathrm{PH} \\
(\mathrm{cm})\end{array}$ & $\begin{array}{c}\text { AAc } \\
(\mathrm{mg} \%)\end{array}$ & $\begin{array}{c}\text { Correlation } \\
\text { with Y/P } \\
(\mathrm{Kg})\end{array}$ \\
\hline DFF (days) & $-\mathbf{0 . 2 8 7}$ & -0.0191 & 0.0010 & 0.144 & -0.0574 & 0.0188 & -0.200 \\
PGF (\%) & -0.159 & $\mathbf{- 0 . 0 3 4 5}$ & 0.0015 & 0.117 & -0.107 & 0.0136 & -0.168 \\
DFFM (days) & -0.121 & -0.021 & $\mathbf{0 . 0 0 2 5}$ & 0.074 & -0.113 & 0.0164 & -0.162 \\
IFW (gm) & -0.0574 & -0.0056 & 0.00025 & $\mathbf{0 . 7 1 9}$ & -0.0369 & 0.0031 & $0.622^{*}$ \\
PH (cm) & 0.0378 & 0.0085 & -0.00064 & -0.0611 & $\mathbf{0 . 4 3 5}$ & 0.0035 & 0.423 \\
AAc (mg \%) & -0.1725 & -0.0151 & 0.00128 & 0.0719 & 0.0491 & $\mathbf{0 . 0 3 1}$ & -0.034 \\
\hline
\end{tabular}

Residual effect: 0.307

DFF - Days to first flowering; PGF - Pollen grain fertility, DFFM - Days to first fruit maturity; IFW - Individual fruit weight; PH - Plant height; AAc - Ascorbic Acid content; Y/P - Yield per plant

In the present investigation, after analyzing principal component, three main principal components were found which explained $79.14 \%$ of total variability (Table 3 ). First principal component accounted $38.68 \%$ of total variability and consisted of days to first flowering, pollen grains fertility and days to first fruit maturity Individual fruit weight and yield per plant were the traits of second main component and plant height and ascorbic acid content were the important characters of third principal component. The second and third principal components contributed $24.59 \%$ and $15.87 \%$ of total variability, respectively (Table 3 ). Henareh et al. (2015) conducted an experiment on 97 tomato land races where they found three main components which explained $71.6 \%$ of total variability in principal component analysis. In another study, Chernet et al. (2014) tested 36 tomato genotypes where they obtained six principal components explaining $83.03 \%$ of total variability. 
Table 3. Major three principal components of seven tomato traits

\begin{tabular}{lccc}
\hline \multicolumn{1}{c}{ Variables } & PC1 & PC2 & PC3 \\
\hline Days to first flowering & 0.485 & 0.074 & 0.127 \\
Pollen grain fertility & 0.499 & 0.021 & -0.098 \\
Days to first fruit maturity & 0.487 & -0.004 & -0.041 \\
Individual fruit weight & 0.107 & 0.607 & -0.481 \\
Plant height & -0.201 & 0.341 & 0.736 \\
Ascorbic acid content & 0.444 & 0.176 & 0.442 \\
Yield per plant & -0.171 & 0.692 & -0.064 \\
\hline Eigen values & 2.71 & 1.72 & 1.11 \\
\hline \% Total Variance & 38.68 & 24.59 & 15.87 \\
Cumulative (\%) & 38.7 & 63.3 & 79.2 \\
\hline
\end{tabular}

Dendrogram was constructed using Ward's method, in which 14 tomato genotypes were grouped into five clusters (Fig. 1 \& Table 4). Reddy et al. (2013) also worked on 19 tomato genotypes and found five clusters by cluster analysis. In the present study, cluster I had maximum number of genotypes. It had six genotypes named; Marglobe-II, Burpi big, Cl-170-0-20-2-0, Derinia, Hot sent, and Manik. On the other hand, cluster III had three genotypes and both cluster II and IV had two genotypes and cluster V had only one genotype (Fig. 1).

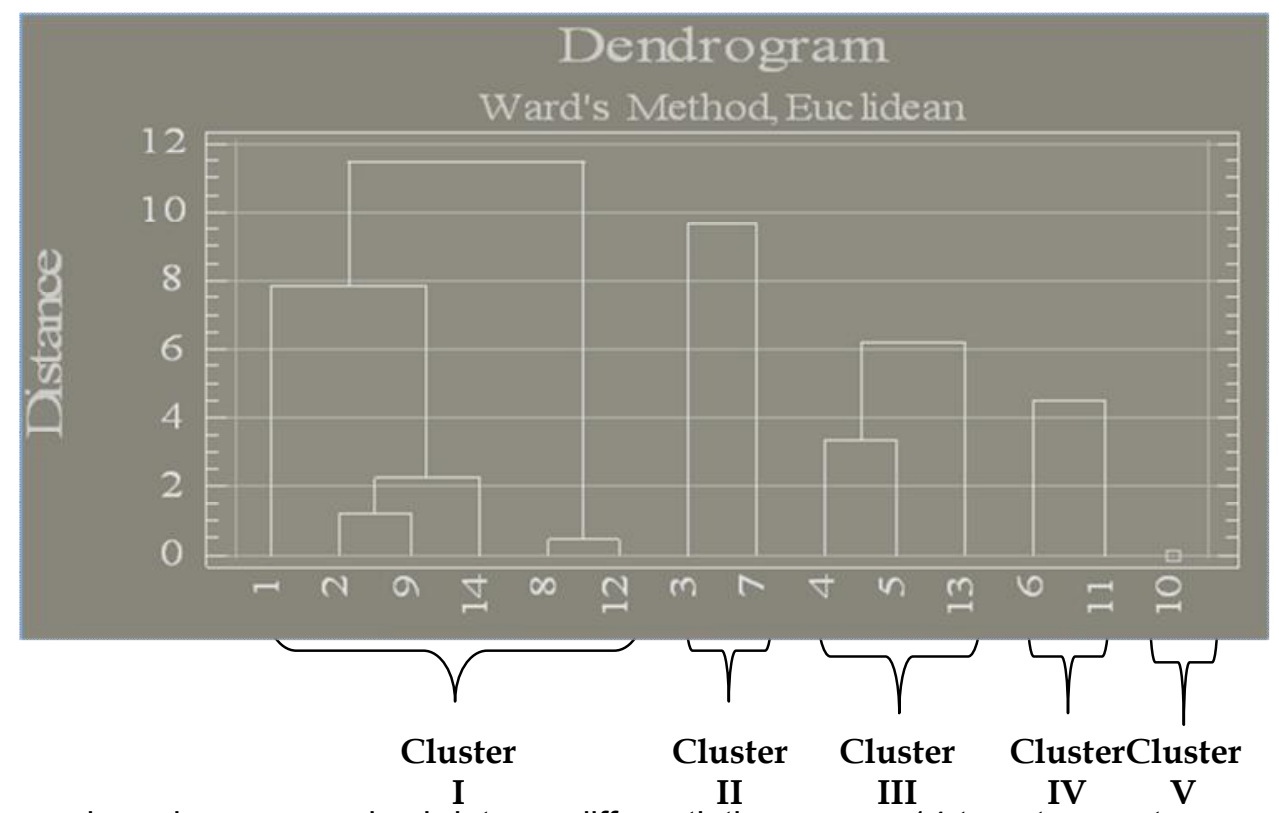

Fig. 1. Dendrogram based on summarized data on differentiation among 14 tomato genotypes according to Ward's method.

Cluster I mainly consist majority of genotypes (42.86\%) which took maximum days (133.97 days) for fruit maturity and gave moderate performance in case of first flowering, fruit weight, pollen grain fertility and ascorbic acid content, with lowest yield $(0.378 \mathrm{Kg} / \mathrm{plant})$. Cluster II contained genotypes $(14.29 \%)$ having the characteristics of lowest flowering period (74.82 days) as compared to cluster I, III, IV and V. This cluster also showed intermediate results in other parameters (Table $4 \& 5$ ). 
Table 4. Distribution of 14 tomato genotypes in different clusters based on Euclidian distance following Ward's method

\begin{tabular}{cccl}
\hline $\begin{array}{c}\text { Cluster } \\
\text { number }\end{array}$ & $\begin{array}{c}\text { Number of } \\
\text { genotypes }\end{array}$ & Percentage (\%) & \multicolumn{1}{c}{ Name of genotypes } \\
\hline I & 6 & 42.86 & Marglobe-II, Burpi big, Cl-170-0-20-2-0, Derinia, \\
II & 2 & 14.29 & Hot sent, and Manik \\
III & 3 & 21.43 & Wokari and Big cherry \\
IV & 2 & 14.29 & Okiton no.9 \\
V & 1 & 7.14 & Cl-3d-0-99 \\
\hline
\end{tabular}

As compared to other clusters, genotypes (21.43\%) belonged to cluster III gave the best performance, as it showed relatively highest value in case of fruit weight, pollen grain fertility, ascorbic acid content and yield per plant. Cluster IV comprised genotypes (14.29\%) with lowest ascorbic acid content whether cluster V contained only one genotype which showed poor results in individual fruit weight, pollen grain fertility and ascorbic acid content (Table 5). Henareh et al. (2015) classified 97 tomato genotypes into five clusters by Ward method where early maturing, high yielder, large fruited, late maturing and genotypes with high acidity were fell in cluster I, II, III, IV and V, respectively.

Table 5. Cluster mean values of 7 different characters of 14 genotypes of tomato

\begin{tabular}{lccccc}
\hline Characters & $\mathrm{I}$ & $\mathrm{I}$ & $\mathrm{II}$ & $\mathrm{IV}$ & $\mathrm{V}$ \\
\hline Plant Height & 75.42 & 68.86 & 73.37 & 61.18 & 138.30 \\
& $\mathrm{I}$ & $\mathrm{I}$ & $\mathrm{I}$ & $\mathrm{L}$ & $\mathrm{H}$ \\
Days to first flowering & 78.75 & 74.82 & 80.97 & 78.21 & 78.07 \\
& $\mathrm{I}$ & $\mathrm{L}$ & $\mathrm{H}$ & $\mathrm{I}$ & $\mathrm{I}$ \\
Days to fruit maturity & 133.97 & 131.05 & 133.47 & 130.65 & 129.50 \\
& $\mathrm{H}$ & $\mathrm{I}$ & $\mathrm{I}$ & $\mathrm{I}$ & $\mathrm{L}$ \\
Individual fruit weight & 26.10 & 32.5 & 40.83 & 31.29 & 23.75 \\
& $\mathrm{I}$ & $\mathrm{I}$ & $\mathrm{H}$ & $\mathrm{I}$ & $\mathrm{L}$ \\
Pollen grain fertility & 91.56 & 59.23 & 92.32 & 88.6 & 47.06 \\
& $\mathrm{I}$ & $\mathrm{I}$ & $\mathrm{H}$ & $\mathrm{I}$ & $\mathrm{L}$ \\
Ascorbic acid content & 25.33 & 19.83 & 26.43 & 16.38 & 18.96 \\
& $\mathrm{I}$ & $\mathrm{I}$ & $\mathrm{H}$ & $\mathrm{L}$ & $\mathrm{I}$ \\
Yield per plant & 0.378 & 0.625 & 0.640 & 0.424 & 0.511 \\
& $\mathrm{~L}$ & $\mathrm{I}$ & $\mathrm{H}$ & $\mathrm{I}$ & $\mathrm{I}$ \\
\hline
\end{tabular}

Here, $\mathrm{H}=$ High, $\mathrm{I}=$ Intermediate, $\mathrm{L}=$ Low

\section{Conclusion}

The present experiment was conducted on seven characters of 14 genotypes of tomato for studying field performance and genetic diversity where the presence of wide diversity among the characters was found. Based on the present findings, World champion and Big cherry may be considered as superior varieties among the fourteen genotypes and individual fruit weight may be considered as an important criterion for yield improvement. This analysis could be beneficial for the further breeding program for utilizing the genotypes and for effective selection for boosting yield in tomato. 


\section{References}

Ali, W., Jilani, M.S., Naeem, N., Waseem, K., Khan, J., Ahmad, M.J. and Ghazanfarullah. 2012. Evaluation of different hybrids of tomato under the climatic conditions of Peshawar. Sarhad Journal of Agriculture, 28(2): 207-212.

Bai, Y. and Lindhout, P. 2007. Domestication and breeding of tomatoes; what have we gained and what can we gain in the future? Annals of Botany, 100: 1085-1094.

Bhutani, R.D. and Kallo, G. 1983. Genetics of carotenoids and lycopen in tomato ( Lycopersicon esculentum Mill). Genetic Agraria, 37: 1-6.

Chernet, S., Belew, D. and Abay, F. 2014. Genetic diversity studies for quantitative traits of tomato (Solanum lycopersicon L.) genotypes in Western Tigray, Northern Ethiopia. Journal of Plant Breeding and Crop Science, 6(9): 105-113.

Dewey, D.R. and Lu, K.H. 1959. A correlation and path co-efficient of created wheat grass production. Agronomy Journal, 51: 515518.

Dudi, B.S. and Kallo. 1982. Correlation and Path Analysis studies in tomato. Haryana Journal of Horticultural Sciences, 11(1\&2): $122-126$.

FAO. 2008. FAOstat database collection, available in FAO.org

FAOSTAT. 2012. FAOstat database collection, available in FAO.org

Gur, A. and Zamir, D. 2004. Unused natural variation can lift yield barriers in plant breeding. PLoS Biology, 2(10): 245.

Henareh, M., Dursun, A., Mandoulakani, B.A. 2015. Genetic diversity in tomato landraces collected from Turkey and Iran revealed by morphological characters. Acta Scientiarum Polonorum Hortorum Cultus, 14(2): 87-96.

Holland, S.M. 2008. Principal component analysis (PCA). Department of Geology, University of Georgia, Athens GA, 30: 602-2501.

Islam, M.S. and Khan, S. 1991. Variability and character association in tomato. Bangladesh Journal of Plant Breeding and Genetics, 4(1\&2): 49-53.

Osei, M.K., Bonsu, K.O., Agyeman, A. and Choi, H.S. 2014. Genetic diversity of tomato germplasm in Ghana using morphological characters. International Journal of Plant Soil Science, 3(3): 220-231.

Plummer, D.T. 1971. An introduction to practical biochemistry. Tata McGrow Hill Pub. Com: Ltd. Bombay, New Delhi 229.

Reddy, B.R., Reddy, M.P., Reddy, D.S. and Begum, H. 2013. Correlation and path analysis studies for yield and quality traits in tomato (Solanum lycopersicum L.). IOSR Journal of Agricultural and Veterinary Science, 4: 56-59.

Singh, J.K., Singh, J.P., Jain, S.K. and Aradhana, J. 2004. Correlation and path coefficient analysis in tomato. Progressive Agriculture, 36(1): 82-86.

Taylor, L.B. 1986. Biosystematics of the tomato. In: JG Atherton and J Rudich (Editors), Chapman and Hall, London. 1-34.

Weber, C.R. and Moorthy, B.R. 1952. Heritable and non-heritable relationship and variability of oil content and agronomic characters in the $F_{2}$ generation of soybean crosses. Agronomy Journal, 44: 202-209. 